\title{
Plutonium Immobilization Can Loading FY98 Year End Design Report
}

by

E. Kriikku

RECORDS ADMINISTRATION

Westinghouse Savannah River Company

Savannah River Site

Aiken, South Carolina 29808

C. Ward

M. Stokes

B. Randall

J. Steed

R. Jones

This paper was prepared in connection with work done under the above contract number with the $U$. $S$. Department of Energy. By acceptance of this paper, the publisher and/or recipient acknowledges the U. S. Government's right to retain a nonexclusive, royalty-free license in and to any copyright covering this paper, along with the right to reproduce and to authorize others to reproduce all or part of the copyrighted paper. 


\section{DISCLAIMER}

This report was prepared as an account of work sponsored by an agency of the United States Government. Neither the United States Government nor any agency thereof, nor any of their employees, makes any warranty, express or implied, or assumes any legal liability or responsibility for the accuracy, completeness, or usefulness of any information, apparatus, product, or process disclosed, or represents that its use would not infringe privately owned rights. Reference herein to any specific commercial product, process, or service by trade name, trademark, manufacturer, or otherwise does not necessarily constitute or imply its endorsement, recommendation, or favoring by the United States Government or any agency thereof. The views and opinions of authors expressed herein do not necessarily state or reflect those of the United States Government or any agency thereof.

This report has been reproduced directly from the best available copy.

Available to DOE and DOE contractors from the Office of Scientific and Technical Information, P. O. Box 62, Oak Ridge, TN 37831; prices available from (423) 576-8401.

Available to the public from the National Technical Information Service, U. S. Department of Commerce, 5285 Port Royal Road, Springfield, VA 22161. 
WSRC-TR-98-00310

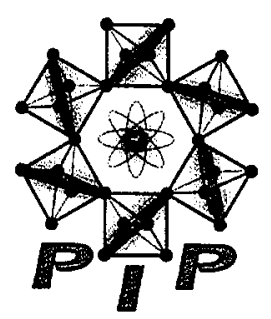

Plutonium Immobilization

Can Loading FY98 Year End Design Report (U)

September 18, 1998

Westinghouse Savannah River Company

Savannah River Site

Aiken, SC 29808 


\title{
Plutonium Immobilization \\ Can Loading FY98 Year End Design Report (U)
}

The following Plutonium Immobilization Team
Members contributed to this report.

\author{
Greg Dyches \\ SRTC/EES \\ James Fiscus \\ SRTC/EES \\ Lee Hamilton \\ SRTC/EES \\ Harriet Haynes \\ SRTC/EES \\ Robert Jones
NMS\&S \\ Eric Kriikku \\ SRTC/EES \\ Bill Randall \\ NMS\&S \\ Howard Reed \\ SRTC/EES \\ Michael Restivo \\ SRTC/EES \\ Lane Rogers \\ SRTC/EES \\ Jim Steed \\ NMS\&S \\ Mitchell Stokes \\ SRTC/EES \\ Clyde Ward \\ SRTC/EES
}


Plutonium Immobilization

Can Loading FY98 Year End Design Report (U)

Approvals

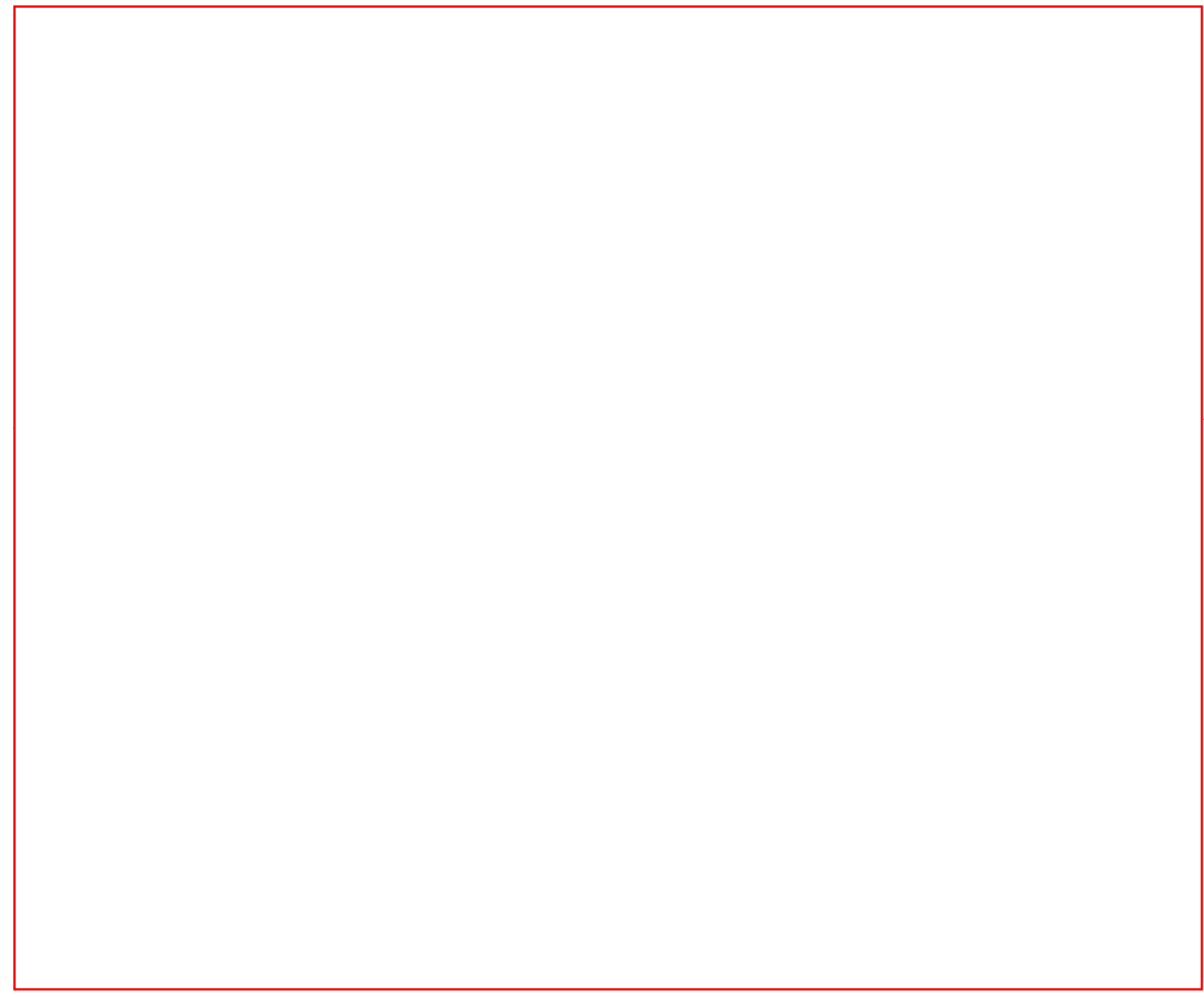




\section{Plutonium Immobilization \\ Can Loading FY98 Year End Design Report (U)}

\section{Table of Contents}

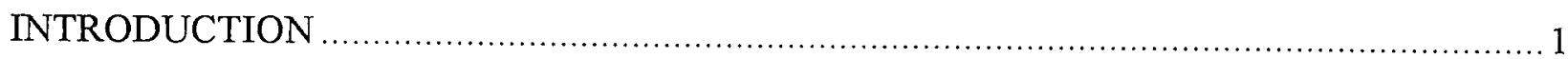

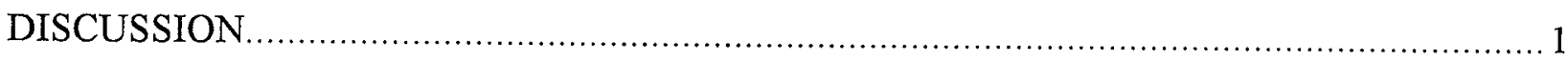

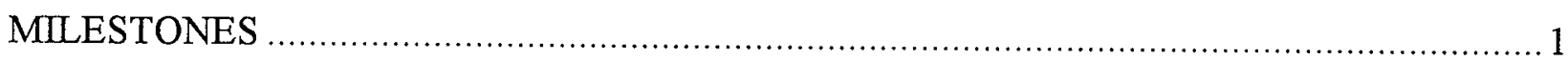

CAN SIZE EVALUATION- February 13, 1998 (WSRC-TR-98-00051) ............................. 2

EQUIPMENT REVIEW - May 1, 1998 (WSRC-TR-98-00164) ......................................... 2

Table 1 - Can Loading Recommended Equipment ............................................... 2

PRELIMINARY CONCEPTS - May 29, 1998 (WSRC-TR-98-00165) ................................... 3

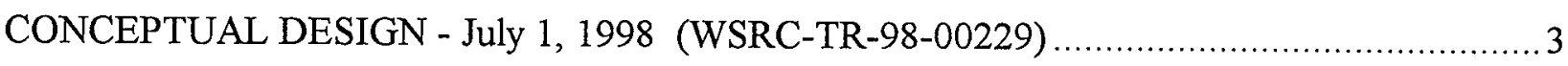

PRELIMINARY SPECIFICATIONS - September 1, 1998 (WSRC-TR-98-00291) _.................. 3

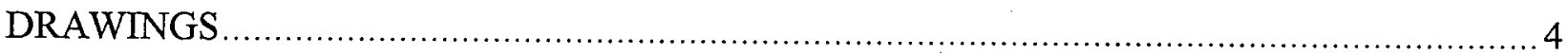

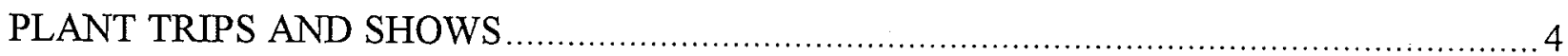

Rocky Flats BNFL Pu repackaging glovebox line - February 19, 1998 ....................... 4

Automation Manufacturing Exposition, Greenville SC - April 13, 1998....................... 5

Linear Motor Trip ( Trip Report NMP-PLS-98-0115) ...................................... 5

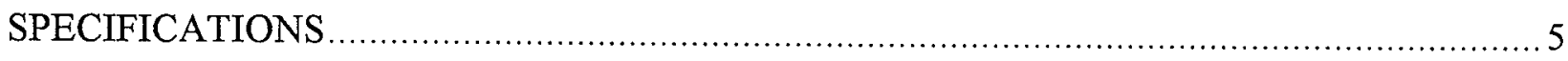

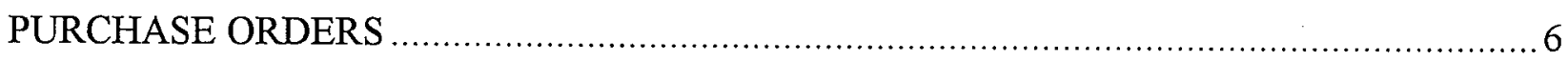

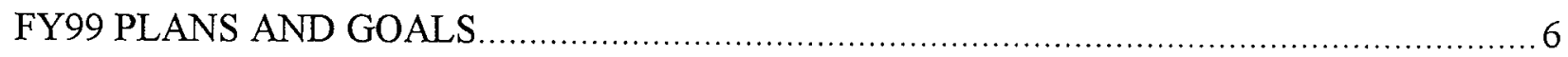

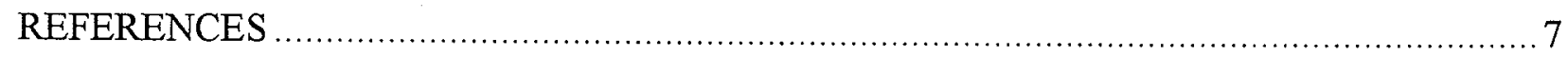

Attachment 1 - Can Loading Process Block Flow Diagram ........................................... 8

Attachment 2 - Can Loading Elevation View ........................................................... 9

Attachment 3 - Can Loading Plan View AA Can Loading Glovebox .................................... 10

Attachment 4 - Can Loading Plan View BB Bagless Transfer Enclosure .............................. 11

Attachment 5 - Can Loading Isometric View ........................................................ 12 


\section{INTRODUCTION}

The Plutonium Immobilization Facility will immobilize plutonium in ceramic pucks and seal the pucks inside welded cans. Remote equipment will place these cans in magazines and the magazines in a Defense Waste Processing Facility (DWPF) canister. The DWPF will fill the canister with glass for permanent storage. This report summarizes FY98 Can Loading work completed for the Plutonium Immobilization Project and it includes summaries of reports on Can Size, Equipment Review, Preliminary Concepts, Conceptual Design, and Preliminary Specification. Plant trip reports for the Greenville Automation and Manufacturing Exposition, Rocky Flats BNFL Pu repackaging glovebox line, and vendor trips are also included.

\section{DISCUSSION}

Two goals of the Plutonium Immobilization Project (PIP) design are minimizing operator radiation exposure and preventing the spread of contamination. To accomplish these objectives, systems must automatically package radioactive contaminated ceramic pucks in clean containers and not release contamination. Traditional methods of removing plutonium from process gloveboxes in preparation for packaging involves the use of manual bagout procedures utilizing plastic bags. This method is not acceptable in the Plutonium Immobilization Project. Engineers at the Savannah River Site (SRS) developed a system for removing plutonium from a glovebox directly into an all metal, welded, leaktight container, free of external contamination. The process, known as bagless transfer, utilizes a Tungsten-Inert-Gas (TIG) welding process to seal radioactive material in a can. The process then separates the transfer can from the glovebox environment while maintaining glovebox and can integrity. A semi-automated bagless transfer unit is in operation at the SRS FB-Line Plutonium Facility. The Plutonium Immobilization Can Loading operations will use this system as a baseline.

\section{MILESTONES}

The following lists the FY98 Plutonium Immobilization Can Loading milestones required by NMSS, completion dates, and comments for each item. Several milestones are also PIP milestones.

\begin{tabular}{lll} 
Milestone Date & Completed & Comments \\
\hline FY98 Schedule & $1 / 16 / 98$ & Copy in job folder \\
Can Size Report* & $2 / 15 / 98$ & Copy in job folder \\
Equipment Review* & $5 / 1 / 98$ & Copy in job folder \\
Preliminary Concepts* & $5 / 28 / 98$ & Copy in job folder \\
MOX Vendor Review* & $7 / 1 / 98$ & Cancelled \\
Conceptual Design* & $7 / 1 / 98$ & Copy in job folder \\
Preliminary Specifications & $9 / 1 / 98$ & Copy in job folder \\
Year End Design Report & $9 / 18 / 98$ & This Report \\
Procure Equipment & $9 / 18 / 98$ & In progress \\
& & \\
& &
\end{tabular}




\section{CAN SIZE EVALUATION- February 13, 1998 (WSRC-TR-98-00051)}

This report (ref. 1) evaluated various can parameters such as; can diameter, can wall thickness, and can length. Recommendations include a 3 -inch outer can diameter based on the DWPF canister neck size limitations and a 0.06-inch nominal wall thickness based on the SRS FB-Line Bagless Transfer can experience. However, can wall thickness requires more analysis to verify that hot DWPF glass will not compromise can integrity. This report considered three different nominal can lengths; 10 inch, 20 inch, and 80 inch. The disadvantages for the 10-inch can include; high number of can loading units required to meet production rates and the associated high number of support process operations. The disadvantages for the 80-inch can include; high development costs, high technical risk, and challenging glovebox operations due to the large size and weight. Advantages for the 20-inch can include; the design is based on the SRS FB-Line Bagless Transfer System, the can size and weight are compatible with glovebox operations, technical risk is low, and cycle time required to meet production is acceptable. This report recommended a 20-inch tall can for the Plutonium Immobilization Project Can Loading System.

\section{EQUIPMENT REVIEW - May 1, 1998 (WSRC-TR-98-00164)}

This report (ref. 2) started with the Plutonium Immobilization Plant Process Flow Diagram for Can Loading and made a detailed Can Loading Block Flow Diagram (see attachment 1). From this, equipment options for each step were evaluated based on equipment advantages and disadvantages. Recommendations for equipment options were made for each process step. Table 1(below) summarizes these recommendations.

\section{Table 1 - Can Loading Recommended Equipment}

\section{Process Step}

Load Pucks into cans

Transport trays from elevator

Store trays

Load pucks in cans

Fill can with helium and insert plug

Transport plugs into glovebox

View Operations

Bagless Can Loader (Seal Can)

Bagless transfer

View Operations

Can Swipe and weld inspection

Swipe can

Count swipe

Leak check can (weld inspection)

View operations

\section{Recommended Equipment}

Magnetic coupled linear transport

Custom vertical lift

Cartesian robot

Helium atmosphere glovebox and Cartesian robot. (later report changed this to Helium backfill system )

Preload plug in puck can

Color cameras

SRS bagless transfer system

Color cameras

Jointed arm robot

Standard counter

Mass spectrometry(Bell jar Technique)

Color cameras 
Table 1 - Can Loading Recommended Equipment (cont.)

\author{
Process Step \\ Open can and remove pucks (reject cans) \\ Receive can \\ Cut can \\ Place pucks on tray \\ Handle waste \\ Transport tray to puck loading robot \\ View operations
}

\author{
Recommended Equipment \\ Jointed arm robot \\ Diametrically opposed cutters \\ Jointed arm robot \\ Jointed arm robot \\ Shared workcell space \\ Color cameras
}

The can loading processes can be accomplished remotely with the recommended equipment and a sufficient equipment development effort.

\section{PRELIMINARY CONCEPTS - May 29, 1998 (WSRC-TR-98-00165)}

This report (ref. 3) discusses five can-loading conceptual designs and lists the advantages and disadvantages for each concept. The report recommends a concept that uses a Cartesian robot to load pucks into puck cans and a six-degree of freedom robot to load and unload cans in the bagless transfer system. Elements from this concept need to be tested to ensure a successful conceptual design.

\section{CONCEPTUAL DESIGN - July 1, 1998 (WSRC-TR-98-00229)}

This report (ref. 4) discussed the Plutonium Immobilization can loading conceptual design. The process block flow diagram (attachment 1), detailed the required can loading steps and is based on the Plutonium Immobilization Plant, First Stage Immobilization, Process Flow Sheet Drawing. Attachments 2 through 5 show the can loading plan, elevation, and isometric views. This report recommended that trays of pucks be staged in the can loading glovebox, a 3 degree of freedom Cartesian robot load the pucks into the puck cans, a helium backfill system be used to introduce helium into the puck cans in lieu of a helium atmosphere glovebox and insert the hollow plug into the can, a six axis robot be used to handle the full puck cans, and that the swiping operations include the bagless transfer can holder.

This report included a process block diagram, process description, preliminary equipment specifications, and several can loading issues. This report identifies loading pucks into cans and backfilling cans with helium as top priority can loading development areas. It was noted that all equipment items in the can loading conceptual design must be tested, integrated, and demonstrated to ensure a successful Plutonium Immobilization can loading system.

\section{PRELIMINARY SPECIFICATIONS - September 1, 1998 (WSRC-TR-98-00291)}

This report (ref. 5) discusses the Plutonium Immobilization can loading preliminary equipment specifications and included a process block flow diagram, process description, equipment list, preliminary equipment specifications, plan and elevation sketches, and some commercial catalogs. Potential vendors were identified for some of the listed equipment in this report. Tray staging lifts were specified in this report that are compatible with the transfer cart. A proposal involving the use of a low cost dedicated AGV to move loaded puck cans from can loading to NDA was 
included. This report also includes estimated costs for equipment. Several assembly drawings of some of the EES designed systems were attached. This report also identifies loading pucks into cans and backfilling cans with helium as the top priority can loading development areas.

\section{DRAWINGS}

The following can loading drawings can be found in the Preliminary Specifications report.

- Can Loading Process Block Flow Diagram -

Flowchart of the Can Loading process

- Can Loading Elevation View -

Elevation view of the Can Loading process area

- Can Loading Plan View AA, Can Loading Glovebox -

Top view of the Can Loading Glovebox

- Can Loading Plan View BB, Bagless Transfer Enclosure -

Top view of the Bagless Transfer Enclosure

- Can Loading Isometric View -

Isometric diagram of the Can Loading process area

- Helium Backfill Arrangement -

Shows a preliminary specification of the Helium Backfill arrangement

- Bagless Transfer Arrangement -

Shows a preliminary specification of the Bagless Transfer arrangement

- 30" Can Detail -

Show the details of the $30^{\prime \prime}$ Can

- Welded Hollow Plug -

This shows the details of the hollow plug used in the Can Loading process

- Sealed Can Detail -

Show the details of a sealed can

\section{PLANT TRIPS AND SHOWS}

\section{Rocky Flats BNFL Pu repackaging glovebox line - February 19, 1998}

The purpose of this trip was to view the BNFL Pu repackaging glovebox line at Rocky Flats. This system is being built and functionally tested in a Denver warehouse and may be installed at Rocky Flats. The line is a series of gloveboxes that will receive Rocky flats Pu oxides and metals, stabilize them and package them for shipping and storage. The system uses a six-axis robot to place the Pu into furnaces for drying. The same robot removes the furnace boats from the furnace, and forwards it to the next glovebox where the Pu is loaded into 3013 convenience cans via a sealed dumper. The convenience can is placed inside a bagless transfer can. This system uses a horizontal bagless transfer with a rotating sphincter seal for containment. The bagless can is welded closed and cut with a laser and placed in a second laser welded can. This final can is smear tested, assayed, and leak tested. Items that could be applied to SRS Immobilization included oxide handling (mixer dumper), air operated linear positioner, the automated swipe and leak test stations, and the can loading system including laser. 


\section{Automation Manufacturing Exposition, Greenville SC - April 13, 1998}

The purpose of this trip was to identify technologies and suppliers the SRS team can draw on during the development of the Pu Immobilization equipment. Two hundred and fifty automation suppliers were represented at the show and many of novel ideas were available for consideration.

Exhibits at the show ranged from common automation building blocks like air cylinders, flexible conduit, cabinets, controls, ball screw actuators, grippers and control systems to more complex machinery including AGVs, machine vision, and conveyors of every type. The show was an excellent opportunity to view equipment without the flash and crowd found at the big-city shows. Also at the show were system integrators, automation design firms, software providers and job shops capable of making just about anything. Of particular interest was Machine Kinetics Corporation, which operates from the Oak Ridge K-25 site and specializes in equipment used in gloveboxes.

\section{Linear Motor Trip ( Trip Report NMP-PLS-98-0115)}

A magnetically coupled cart drive and elevator system was built and demonstrated at WSRC in Bldg. 305-A. The material transport system concept was based on mockup work done for pit manufacturing in FY97 - 98. In addition to the propulsion technology used in this system (underfloor belt driven permanent magnet coupled to iron cart undercarriage), several other technologies were examined for use in the $\mathrm{Pu}$ Immobilization facility in a trip to several vendors. The most applicable technology appears to be linear synchronous motors (LSMs). Axidyne belt drive system could be applicable in special cases, but is limited with drive length and inability to transverse flanges or gaps. Linear induction motors, linear stepping motors, rodless cylinders, and linear motors with moving coil secondaries were also examined. LSMs have the following advantages over the other technologies:

- No low speed cogging

- Capable of a wide range of speed and well controlled

- Adaptable to long lengths (several hundred feet)

- Adaptable to traversing flanges and walls

- No moving components outside of containment barrier. Minimal complex equipment installed in glovebox i.e. only passive cart

- Low degree of self heating

- Load variation tolerant

- Held cart in position without need of additional brake

As a result of this trip, it was determined that LSMs are feasible and cost effective for this application.

\section{SPECIFICATIONS}

Puck Robot - EES wrote a specification for a Cartesian puck robot. This robot will demonstrate removing twenty pucks from a transport tray and placing them in the puck can. The robot will also handle can stubs, the helium backfill hood, and reject cans. Vendor bids are due by $9 / 11$ and the purchase order will be placed before $9 / 30$. 
Puck Pick and Place Machine - EES wrote a specification for a puck pick and place machine. This pick and place machine will load pucks into a puck can. This machine can not perform all the functions the puck robot can, but it is an inexpensive alternative to the puck robot. Vendor bids are due by $9 / 15$ and the purchase order will be placed before $9 / 30$. This may be considered as an alternate to the puck robot.

\section{PURCHASE ORDERS}

Helium Backfill Hood - EES will purchase or fabricate the components required to demonstrate the helium backfill hood. This device will seal to a full puck can, evacuate the can atmosphere, introduce helium into the can, and place the hollow plug into the can. The device will be used to prove the concept and determine required gas pressures, leak rates, and other operating parameters.

\section{FY99 PLANS AND GOALS}

The primary FY99 can-loading goal will be to demonstrate loading pucks into puck cans. EES will purchase and test a Cartesian robot to demonstrate the puck loading process. EES will also purchase and test a simple pick and place device for loading pucks into puck cans as an alternate method. The test objectives will include the following:

- Determining optimal operating procedures, requirements, and tolerances.

- Determining and minimizing puck loading failures.

- Testing various vacuum cups and vacuum pressures for puck lifting.

The second FY99 can-loading goal will be to demonstrate the helium backfill system. EES will design, fabricate, and test a helium backfill system. This demonstration will include moving the hood onto a puck can, filling the can with helium, and inserting the puck can plug. If time and funding permits, the helium hood will be integrated with the Cartesian robot system. The test objectives will include the following:

- Determining optimal operating procedures, requirements, and tolerances.

- Testing seal methods.

- Determining seal leak rates.

The third FY99 can-loading goal will be to demonstrate the tray staging system. EES will design and test a tray staging system. Depending on funding levels, this could be a linear actuator moving a cart working with the Cartesian puck loading robot system or a magnetically coupled cart and two magnetically coupled lift stations working with the Cartesian puck loading robot system. The test objectives will include the following:

- Determine best equipment/method.

- Determining optimal operating procedures, requirements, and tolerances.

- Testing the compatibility between the tray staging system and the puck robot. 


\section{REFERENCES}

1. Plutonium Immobilization Can Loading Puck Can Size Evaluation (U). USDOE Report WSRC-TR-98-00051, Savannah River Site, Aiken, SC 29808 (2/13/98)

2. Plutonium Immobilization Can Loading Equipment Review (U). USDOE Report WSRC-TR98-00164, Savannah River Site, Aiken, SC 29808 (5/1/98)

3. Plutonium Immobilization Preliminary Can Loading Concepts (U). USDOE Report WSRCTR-98-00165, Savannah River Site, Aiken, SC 29808 (5/29/98)

4. Plutonium Immobilization Can Loading Conceptual Design (U). USDOE Report WSRC TR-98-00229, Savannah River Site, Aiken, SC 29808 (7/1/98)

5. Plutonium Immobilization Can Loading Preliminary Specifications (U). USDOE Report WSRC-TR-98-00291, Savannah River Site, Aiken, SC 29808 (9/1/98) 


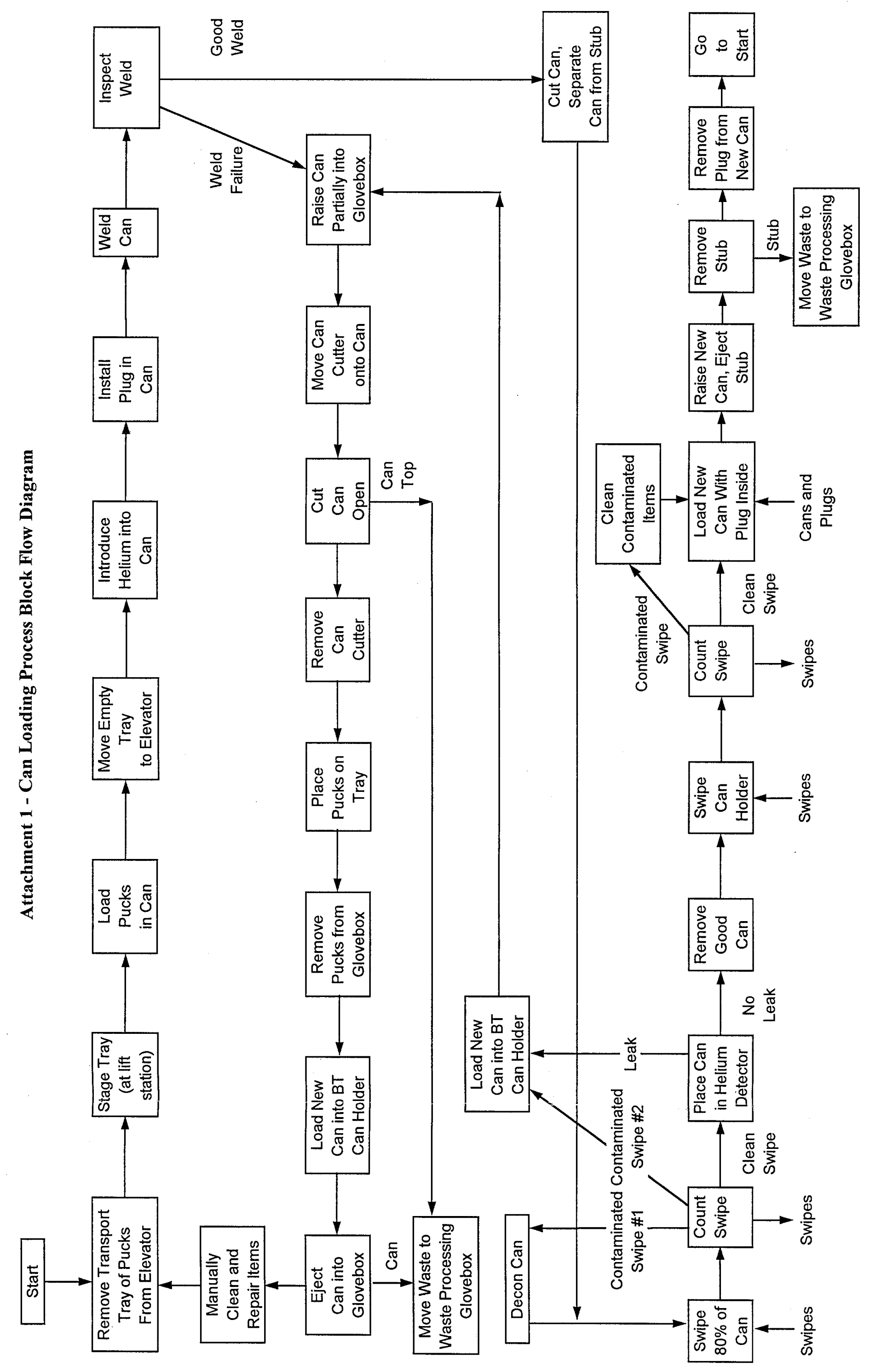




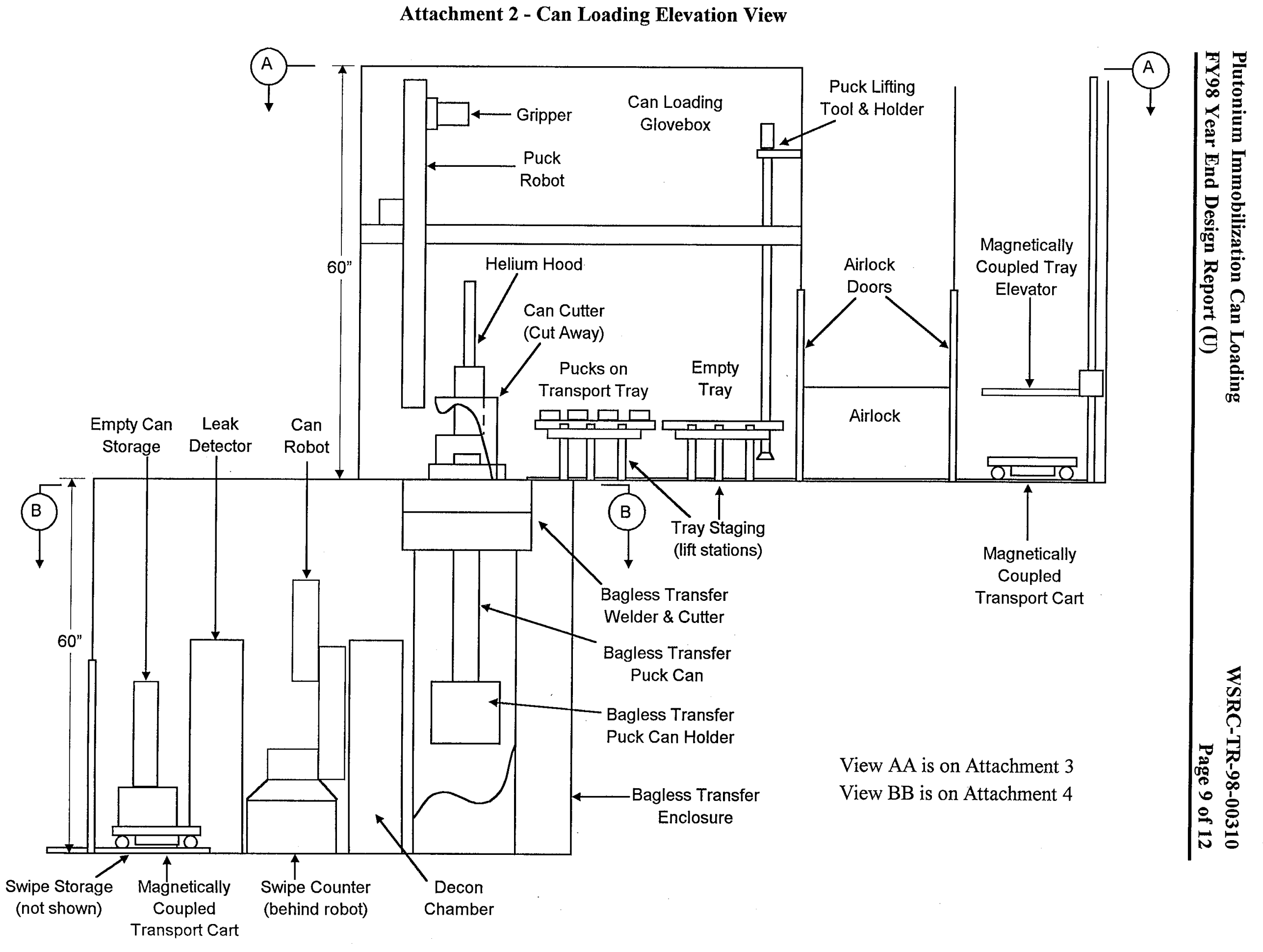




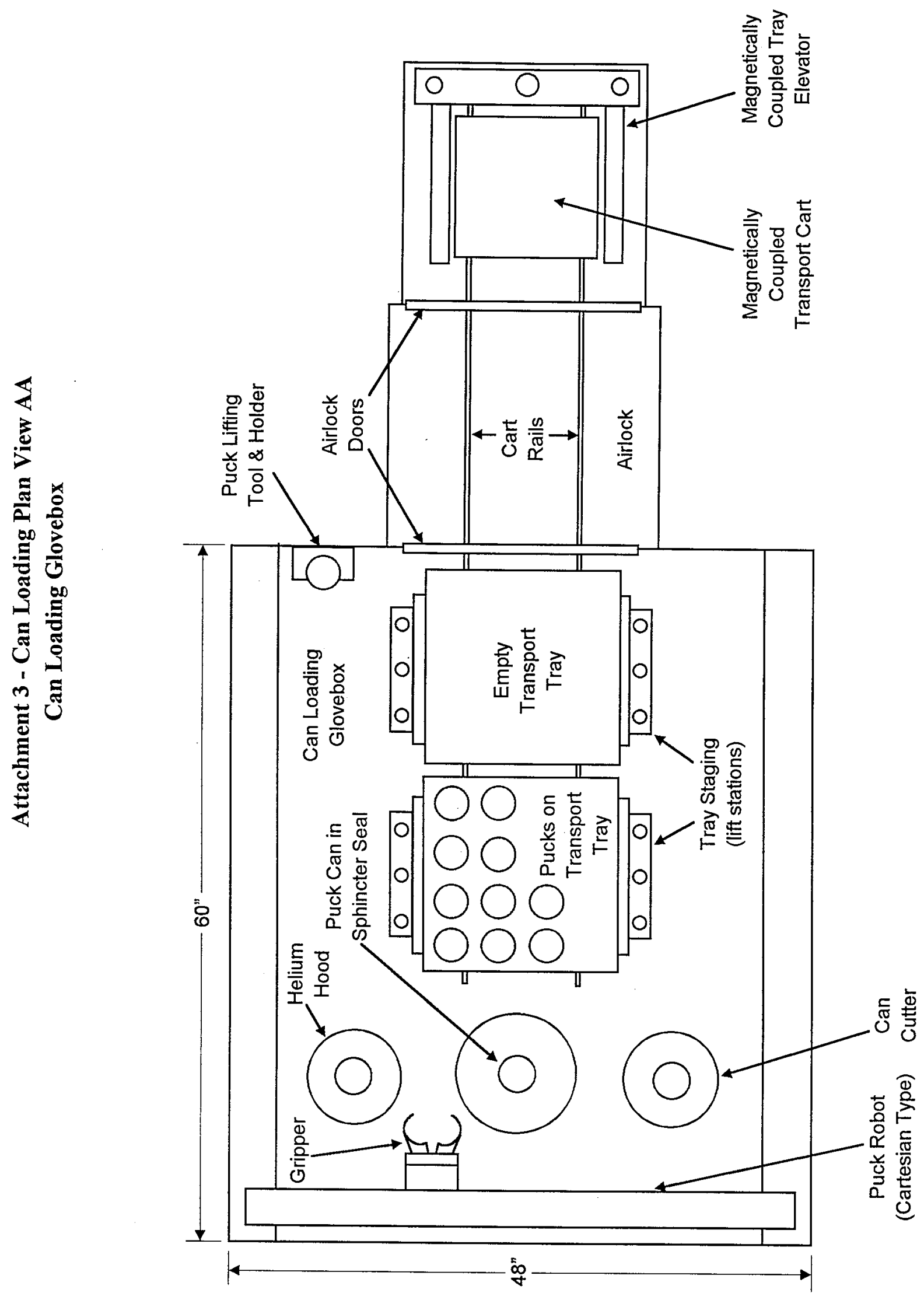




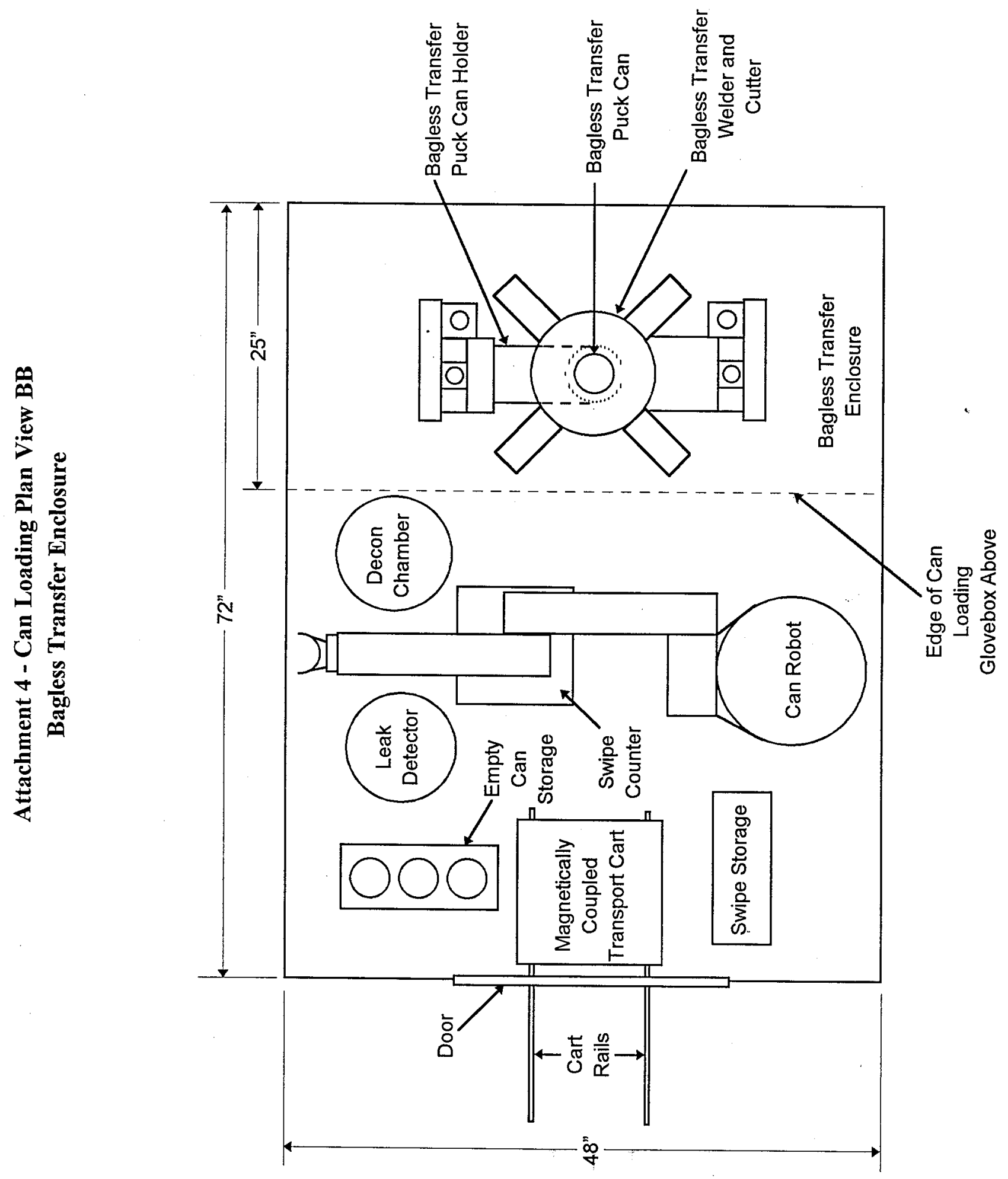




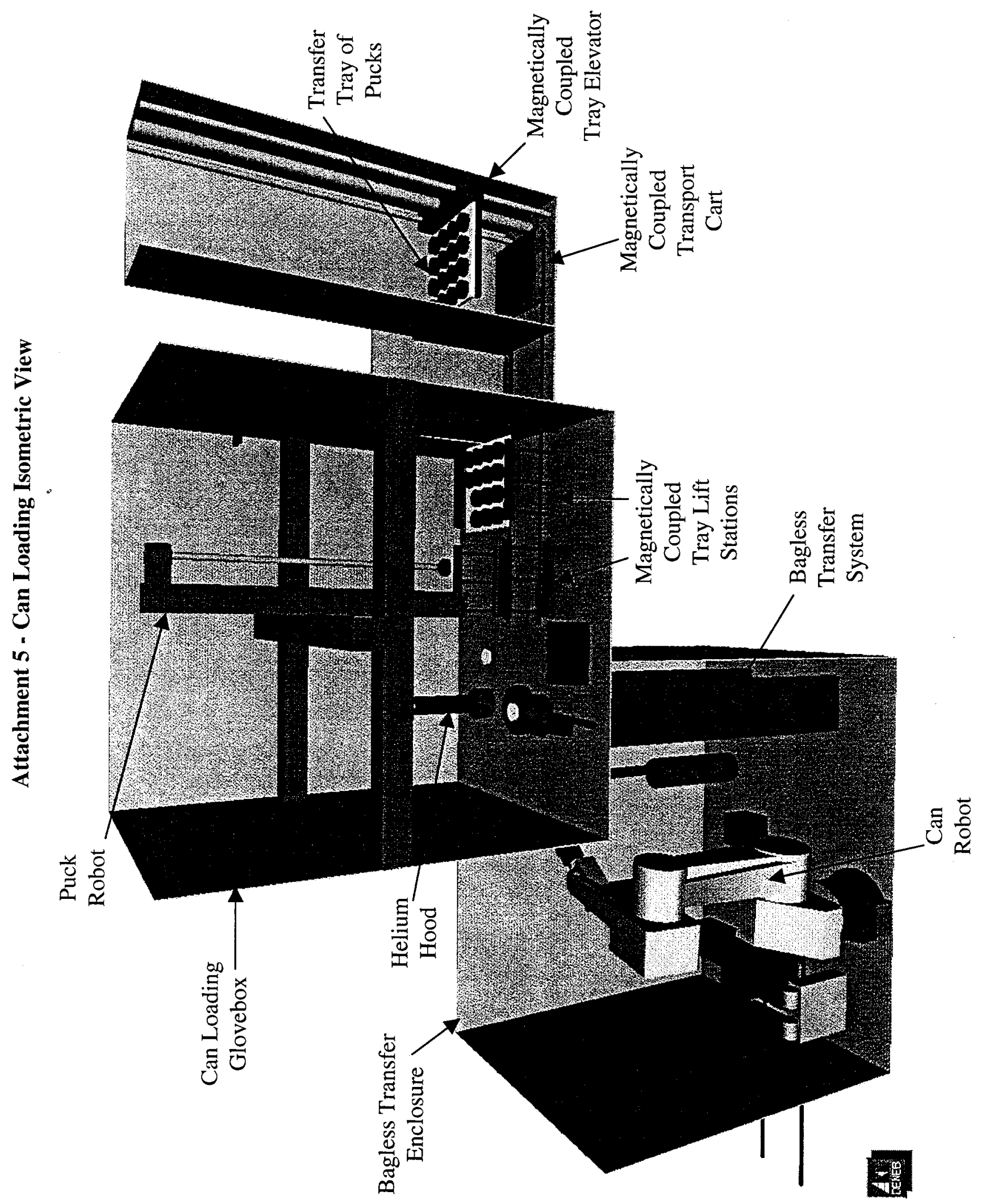

